\title{
Characterization of the relations between morphology and physiological status of the pineal gland in connection with the somatic development level in turkeys reared in Romania
}

\author{
[Caracterização das relações entre morfologia e estado fisiológico da glândula pineal em conexão \\ com o nível de desenvolvimento somático em perus criados na România] \\ R. Lazăr$^{1}$, C. Solcan ${ }^{2}$, C. Creţu $u^{2}$, M. Lazăr ${ }^{2}$, C. Muntean ${ }^{3}$, P.C. Boişteanu ${ }^{1}$ \\ ${ }^{1}$ Faculty of Animal Science Iasi, UASVM Iasi, Alley M. Sadoveanu, 3, Romania \\ ${ }^{2}$ Faculty of Veterinary Medicine Iasi, UASVM Iasi, Alley M. Sadoveanu, 3, Romania \\ ${ }^{3}$ S.C. Galli-Gallo, Braşov, Romania
}

\begin{abstract}
This research started from the premises of the existence of some possible relationships between indole and pineal peptide hormones and the somatic development, with participation of hypothalamic-pituitary complex. Experimental factors, which were the subject of the present paper, influenced the dynamics of corporal mass and fodder consumption, leading to the occurrence of some important structural modifications at the level of pineal gland. The exposure of the individuals to continuous light (photic pinealectomy) produces increases in corporal mass, showing the involvement of the pineal gland in neuro-endocrine-metabolic reactions, which contributes to the maintenance of homeostatic balance, including somatic ones. Biological material was represented by a number of 50 individuals belonging to B.U.T. Big 6 hybrid, reared on soil, on a permanent litter, which could assure the expanding of knowledge area regarding the relation between rearing technology, modulation of some microclimate parameters and growing performances. Were also realised cytometric and hystometric muscular determinations.
\end{abstract}

Keywords: turkey, pineal gland, productive performance

\section{RESUMO}

A pesquisa começou a partir da premissa de que provavelmente existam relações entre indol e hormônios peptídicos pineal e o desenvolvimento somático, com a participação do complexo hipotálamo-hipófise. Fatores experimentais que foram objeto do presente trabalho influenciaram a dinâmica da massa corporal e o consumo de forragem, o que leva à ocorrência de algumas modificações estruturais importantes no nível da glândula pineal. A exposição dos indivíduos à luz contínua (Pinealectomia photic) leva ao aumento de massa corporal, mostrando o envolvimento da glândula pineal em reações neuroendócrino metabólicas, inclusive somáticas, que contribuem na manutenção do equilíbrio homeostático. $O$ material biológico foi representado por um número de 50 indivíduos pertencentes a MAS Big híbrido 6, criados em solo, em uma ninhada permanente, o que poderia garantir a expansão da área de conhecimento a respeito da relação entre a tecnologia de criação, modulação de alguns parâmetros microclimáticos e performances de crescimento. Também foram realizadas por citometria e histometria determinações musculares.

Palavras-chave: peru, glândula pineal, desempenho produtivo

Recebido em 6 de agosto de 2013

Aceito em 2 de março de 2015

E-mail: rlazar@uaiasi.ro 


\section{INTRODUCTION}

Epiphysis is a photosensitive neuro-endocrine organ situated in the geometrical centre of brain, between the corpus callosum and the superior quadratic twin nucleus (Buijs et al. 2006; Boişteanu 2000; Cantwell et al. 2006). In turkeys the pineal gland has the shape of a cone with the base pointing to the skull, presenting a connexion with the ceiling of $3 \mathrm{rd}$ ventricle known as the habenular rod.

Pineal gland in birds contain a circadian oscillator which has a leading role in the temporary organisation of cerebral functions. The secretion of pineal indols has a high regularity, which seems to be essentially endogen, modulated by the alternation of light/dark (L/D) and temperature (Natesan et al., 2002; Okano et al., 2003). The circadian clock by which each avian pinealocite adjusts the transcription is followed by biosynthesis of melatonin rhythmically expressed in the cycle $\mathrm{L} / \mathrm{D}$ and $\mathrm{D} / \mathrm{D}$, both in vivo and in vitro (Michael et al. 2005; Zawilska et al. 1993; Zawilska et al. 2006). In adaptation of the organism to the environment conditions, the pineal gland, through its hormones, doesn't act directly on gonads or on the endocrine system, but acts on the brain and contributes to the adjustment of cerebral functions to environment conditions, reproductive activity being only one part of this process. The pineal gland, through melatonin biosynthesis, is a photo-periodic transducer which mediates the seasonality of the reproductive function (Foster et al. 2002). The involvement of melatonin in the functional hypothalamic-pituitary-gonadal axis is proven by the high level associated to a lower secretion of gonadotropins. The decreasing of melatonin concentration activates the hypothalamicpituitary-gonadal axis through feedback mechanisms (Chong et al. 2003; Skwarlo-Sonta et al. 1999; Schomerus et al. 2005).

The main hormonal factor excreted by the pineal gland, with a modulating action at the level of the hypothalamic-pituitary, is melatonin, whose inhibitory effects on secretion of LH, FSH, prolactin, ACTH and b-endorphin are well known (Csernus et al. 2003).

The molecular and biochemical mechanisms through which avian pineal gland synthesizes melatonin are still insufficiently known. The cellular and molecular components of birds' pineal gland, which interfere in the adjustment of phase or period of circadian oscillations, which produce melatonin, were not identified. It is known that melatonin is synthesized from tryptophan, which is taken from the sanguine flow. This one is converted in 5hydroxytryptophan (5-HTRP) by means of tryptophanhydroxylase (TRH), then in 5hydroxytryptamine (5-HT) with the aid of aromatic amino-acid decarboxylase (AAADC). During the night 5-HT is N-terminal acetylation by means of $\mathrm{N}$-acetyltransferase to form $\mathrm{N}$ acetylserotonin (NAS), a substrate of the final transfer enzyme, which is hydroxyindole-omethyltransferase (HIOMT). NAT and HIOMT activity is intensified at dark due to the increased released of noradrenaline from the sympathetic nerve endings located at the level of cellular membrane of pinealocites (Arendt et al. 1991; Lorenc-Duda 2008; Pryzbylska et al. 2009; Skene et al. 1991).

Melatonin is a lipophilic hormone which diffuses rapidly through membranes and in the blood, where it is catabolized and inactivated in the liver by hydroxylation.

It seems that in birds the circadian rhythm is much more complex that in mammals, because the central nervous system together with the pineal gland and retina act as a whole through nervous and umoral mechanisms (Gwinner et al. 2001; Underwood et al. 2001).

Factors which influence the development of individuals are abiotic factors, represented by light, temperature, air moisture, water chemical composition, atmospheric pressure, hydric pressure, physical and chemical structure of soil and biotic factors influenced by interference of the behaviour relation of the individuals from the same breed or different breeds, which exert a competition, a concurrency. Organisms don't passively obey the action of environment factors, tending to react by different adaptation modalities. Faced with large variations of environment factors, organisms create for themselves a series of structures and functions able to adapt, to self-preserve. An argument in support of this claim is represented by the experimental results regarding relocation of the birds, which were adapted to a rearing system in 
constant dark (DD), which in turn produced significant disorders in the synthesis of melatonin (Zawilska et al. 2006a and b).

Research carried out in the last years enlightened the fact that photo-periodicity act through the pineal gland, not only on seasonal reproductive cycles, but also on feed ingestion, storage of reserve lipids, modification of hairiness in fur animals, and also on hibernation; these aspects being determined by the daily variations of melatonin secretion, with action focused on hypothalamic control of gonadotropins and lactotroph hormone secretion from anterior hypophysis, obtaining variations of gonads, fur, corporal mass and adipose layer due to the physiological context caused by photo-period modifications (Arendt, 1995; Brandstatter et al. 2003; Lewis et al. 2010; Siapes et al. 1989).

Physiological activity of the pineal gland with specific answers for meat production could not be interpreted by monitoring the technological parameters used in turkeys' rearing technological management.

\section{MATERIALS AND METHODS}

The utilised biological material was represented by a number of 50 ear tagged individuals, belonging to B.U.T. Big 6 hybrid. Individuals were reared at soil, on a permanent litter, being exposed to a continuous light programme, assured by 24 lamps with 25 lux intensity, placed at a height of $2 \mathrm{~m}$ from soil. Temperature in rearing shelters was $16^{\circ} \mathrm{C}$ and moisture was $60 \%$. Feeding was made ad libitum, with finishing fodder based on a crude protein content of $18 \%$ and $0.65 \%$ calcium and phosphorous.

Determination of body mass was done every week in the range 17 to 20 weeks. The determination of productive indexes was done: specific consumption and mean daily gain. Determinations regarding the corporal dimensions: torso length, length of stern hull, thoracic perimeter, and determinations regarding corporal indexes: pectoral muscle development index (P.M.D.I.) and compactness index (C.I.) were done at 20 weeks. Interpretation of slaughtering was done by percentage rate of the anatomical parts from carcass.
Histopathological examination focused on gathering, fixation, immersion in paraffin, sectioning at microtome, colouring and microscopic examination, operational times of obtaining techniques for permanent histological sample by paraffin immersion method. The coloration used was HEA.

Somatic muscular histometry utilised a Motic DMWB1-223 digital photonic microscope, calibrated at 3 associations of ocular-objective lens. For calibration an objective micrometer included in the microscope kit (calibration blade) and Motic Images Plus ML, v. 2.0 package were used.

Measurements were taken regarding the great and small diameter of myocytes and the 1st order muscular fascicles and the surface of their transversal section.

To calculate the density of muscular fibres (nr. fibres/mm2 muscles) we numbered the exact amount, at the level of each FM I (Nr. f.m.); then we calculated the transversal surface of FM I (S. FM I)

To calculate the proportion of muscular and connective tissue, at the level of 1 st order muscular fascicles the number of fibres from each F.M. I and their surface on transversal section were established; the transversal surface of muscular fascicles (F.M. I) was calculated.

\section{RESULTS AND DISCUSSIONS}

The aim of the current paper was to identify some technological solutions for rearing and maintenance implied in maximization of somatic development and implicit in the increase in meat production through aviary physiological research.

Photo-sensibility of epiphysis is mainly due to the succession of serotonin and melatonin, and the nocturne secretion of melatonin in birds is involved in decreasing feed consumption, specifically feed conversion. Modulation of light threshold for birds aimed for meat production must respect the physiological demands specific for each age category and productive specialization. 
To be able to define the role of the pineal gland in somatic development of individuals, those were subjected to a continuous lighting schedule from 17-20 weeks, a period in which the dynamics of corporal mass was monitored. The obtained data were permanently compared with the ones specified in the hybrid rearing guide.

At 17 weeks, at the end of gravimetric measurements, a mean value for corporal mass of $11,658 \mathrm{~g}$ with $158 \mathrm{~g}$ more than was stated in the rearing guide was obtained. At 18 weeks the recorded values were $240 \mathrm{~g}$ under the value presented in the guide. At 20 weeks, when the individuals were conducted to slaughter, a corporal mass of $13,518 \mathrm{~g}$ with $28 \mathrm{~g}$ more than was stated in the rearing guide was recorded. Consumption index in this period varied between 2.5-2.62 g, light in excess having a stimulating action on physiological anabolism.

From the point of view of commercial appreciation which resulted after slaughter, we can say that in percentage, boneless and skinless breast represent $29.85 \%$ from carcass; upper thigh with bone and skin $14.8 \%$ from which $11.1 \%$ is boneless upper thigh with skin; lower thigh represents $12.19 \%$ from carcass; wing
$10.12 \%$; dorsum together with sternum represent $29.04 \%$ from carcass, tart represents $2.05 \%$.

Appreciation of the corporal development degree was realised by measurements and calculations of the corporal indexes. In the case of B.U.T. Big 6 hybrid reared in Romania, a torso mean length of $45.8 \mathrm{~cm}$ was obtained, the length of stern hull was $25.5 \mathrm{~cm}$ and the thoracic perimeter recorded a value of $73.33 \mathrm{~cm}$. From the corporal indexes P.M.D.I. were calculated, which had a value of $55.67 \mathrm{~cm}$ and C.I. had a value of $160.10 \mathrm{~cm}$.

Cytometric and somatic hystometric studies were done because the dimensions of muscular fibres have a great importance in expressing the physical qualities of meat: texture, tenderness and juiciness. Also, the important role of the thickness of muscular fibres could be deducted by the role played in the chilling time of carcass. Turkey hybrids specialized for meat production, have at slaughter an increased efficiency of breast, a fact which requires a suitable chilling for preventing the obtaining of PSE meat.

Data regarding the cytometric and hystometric elements of somatic musculature in turkeys are presented in Table 1 .

Table 1. Dimensional elements of myocytes and primary muscular fascicles from turkeys' somatic musculature

\begin{tabular}{|c|c|c|c|c|c|c|c|c|}
\hline $\begin{array}{l}\text { Muscle } \\
\text { (area of carcass) }\end{array}$ & Stat. & $\begin{array}{l}\text { Mean } \\
\text { thickness of } \\
\text { muscular } \\
\text { fibres }(\mu) \\
(n=100)\end{array}$ & $\begin{array}{l}\text { Area of } \\
\text { transversal } \\
\text { section of } \\
\text { muscular } \\
\text { fibres }(\mu 2) \\
(\mathrm{n}=100)\end{array}$ & $\begin{array}{l}\text { Area of } \\
\text { transversal } \\
\text { section of } \\
\text { primary } \\
\text { muscular } \\
\text { fascicle }(\mu 2) \\
(n=6)\end{array}$ & $\begin{array}{l}\text { Mean } \\
\text { number of } \\
\text { muscular } \\
\text { fibres per } \\
\text { primary } \\
\text { muscular } \\
\text { fascicle }\end{array}$ & $\begin{array}{l}\text { Density } \\
\text { of } \\
\text { muscular } \\
\text { fibres per } \\
\mathrm{mm} 2 \\
\text { of } \\
\text { muscles }\end{array}$ & $\begin{array}{l}\text { Rate of } \\
\text { muscular } \\
\text { tissue in } \\
\text { muscle } \\
\text { composition } \\
(\%)\end{array}$ & $\begin{array}{l}\text { Rate of } \\
\text { connective } \\
\text { tissue in } \\
\text { muscle } \\
\text { composition } \\
(\%)\end{array}$ \\
\hline \multirow{3}{*}{$\begin{array}{l}\text { Superficial pectoral } \\
\text { (breast) }\end{array}$} & & 52.46 & $2,202.94$ & $418,232.08$ & 110.40 & 264.22 & 65.00 & 35.00 \\
\hline & & 0.73 & 63.14 & $31,849.52$ & 9.89 & 12.99 & 1.13 & 1.13 \\
\hline & $\mathrm{v} \%$ & 13.88 & 28.66 & 17.03 & 20.03 & 10.99 & 3.88 & 7.20 \\
\hline \multirow{3}{*}{$\begin{array}{l}\text { Semimembranosus } \\
\text { (upper thigh) }\end{array}$} & & 49.38 & $2,013.63$ & $329,872.56$ & 102.40 & 311.47 & 71.44 & 28.56 \\
\hline & & 1.13 & 93.55 & $21,781.42$ & 7.37 & 15.87 & 0.80 & 0.80 \\
\hline & $\mathrm{v} \%$ & 22.83 & 46.46 & 14.76 & 16.09 & 11.40 & 2.49 & 6.23 \\
\hline Medial & & 46.78 & $1,818.90$ & $308,860.91$ & 85.00 & 274.80 & 70.63 & 29.37 \\
\hline gastrocnemius & & 1.14 & 89.97 & $20,291.66$ & 6.89 & 9.95 & 0.96 & 0.96 \\
\hline (lower thigh) & $\mathrm{v} \%$ & 24.30 & 49.46 & 14.69 & 18.13 & 8.10 & 3.04 & 7.32 \\
\hline
\end{tabular}

The applied hystometric study enlightened a mean thickness of upper muscular fibres in the case of white meat, with a value of $52.46 \pm 0.73 \mu$ (pectoral musculature, metabolic type of myocytes with glycolytic substrates), in comparison with the contractile fibres from red meat, gathered at the level of lower members, respectively $49.38 \pm 1.13 \mu$ and $46.78 \pm 1.14 \mu$ (thigh and shank musculature, metabolic type of myocytes with oxidative substrates). These dimensional values for myocytes also lead to the same dimensional classification, at the level of primary muscular fascicles. From the point of view of muscular fibre density per area unit a 
maximum density was observed at lower member musculature, respectively at the muscular sample gathered at thigh level (311.45 myocytes $/ \mathrm{mm}^{2}$ ), in comparison with 264.22 myocytes $/ \mathrm{mm} 2$, minimal value recorded for meat sample gathered from the pectoral zone.

Regarding the tisular structure, this study revealed that the greatest rate of pure muscular tissue in the structure of studied muscle $(71.44 \pm 0.80 \%)$ was recorded in the upper thigh musculature, while for pectoral musculature the participation in meat composition of around $2 / 3$ of muscular tissue and almost $1 / 3$ connective tissue was revealed.

At the 20th week the pineal organ enlarged, however the number of follicles still varied between 100 and 120. The marked increase in thickness of the connective tissue septa has been noted (Figure 1a). Some of them created thin branches, which penetrated into the follicular wall and partially separated smaller portions of the follicle. The penetration of connective tissue septa into the pineal lumen has also been observed. Parenchyma of the avian pineal organ consists of three types of cells - pinealocytes, supporting cells and nerve cells.

Supporting cells are represented by ependymallike cells located around the cavities of the pineal follicles and small, round cells present in the outer part of the follicular wall, the elongated pinealocytes with apical prolongations, probably representing the rudimentary-photoreceptor type and the secretory pinealocytes (Figure 1b)

Ependymal-like cells are slim with microvilli or cilia on their apical surface. Simultaneously, pinealocytes' population underwent the transformation, leading to the increase in the percentage of parafollicular cells (Figure 1c). The population of the supporting cells localized peripherally in the follicles is poorly known.

The last type is sparsely represented in young birds but it predominates in sexually mature turkeys. The secretory pinealocytes are also present in the distal part of the pineal stalk (Figure 1d).
The follicular wall was formed by two welldistinguished parts - the basal one consisting of several layers of round or oval cells and the apical one bordering the lumen.

The apical part was composed by the cone shaped and elongated cells. The apical prolongations of the elongated cell were observed sporadically.

Many of these alternations probably affect the pineal secretory process and its regulatory mechanisms. Both bi-polar, elongated cells with prolongations (presumably the rudimentaryphotoreceptor pinealocytes) and round cells classified as the secretory pinealocytes seem to be responsible for the secretory activity of the turkey pineal organ, but their significance may change significantly during ontogeny.

The pineal gland was surrounded rostrally by the well-developed choroids that consisted of elongated cisterns formed by a cuboid epithelium (Figure 2a,b). The accessory pineal tissue was localized caudally to the choroid plexus.

During the light phase, mean melatonin concentrations in the pineal gland and retina of turkeys kept under the long photoperiod were significantly higher compared with those from birds maintained under the regular and short photoperiods. In addition, mean circulating melatonin levels were lowest in the short photoperiod.

Light is the dominant environmental factor controlling melatonin biosynthesis in both the pineal gland and retina. Epiphysis of the turkeys subjected to a long period of light present positive PAS cells loaded with hormones (Figure $3 \mathrm{a})$. The release of these hormones is done during the night when the synthesis is suppressed. Light at night acutely suppresses melatonin synthesis.

Turkeys subjected to a normal light schedule present pinealocytes with the poorest cytoplasm in hormones or the rate of the loaded pinealocytes is lower (Figure 3b). 


\section{Lazăr et al.}
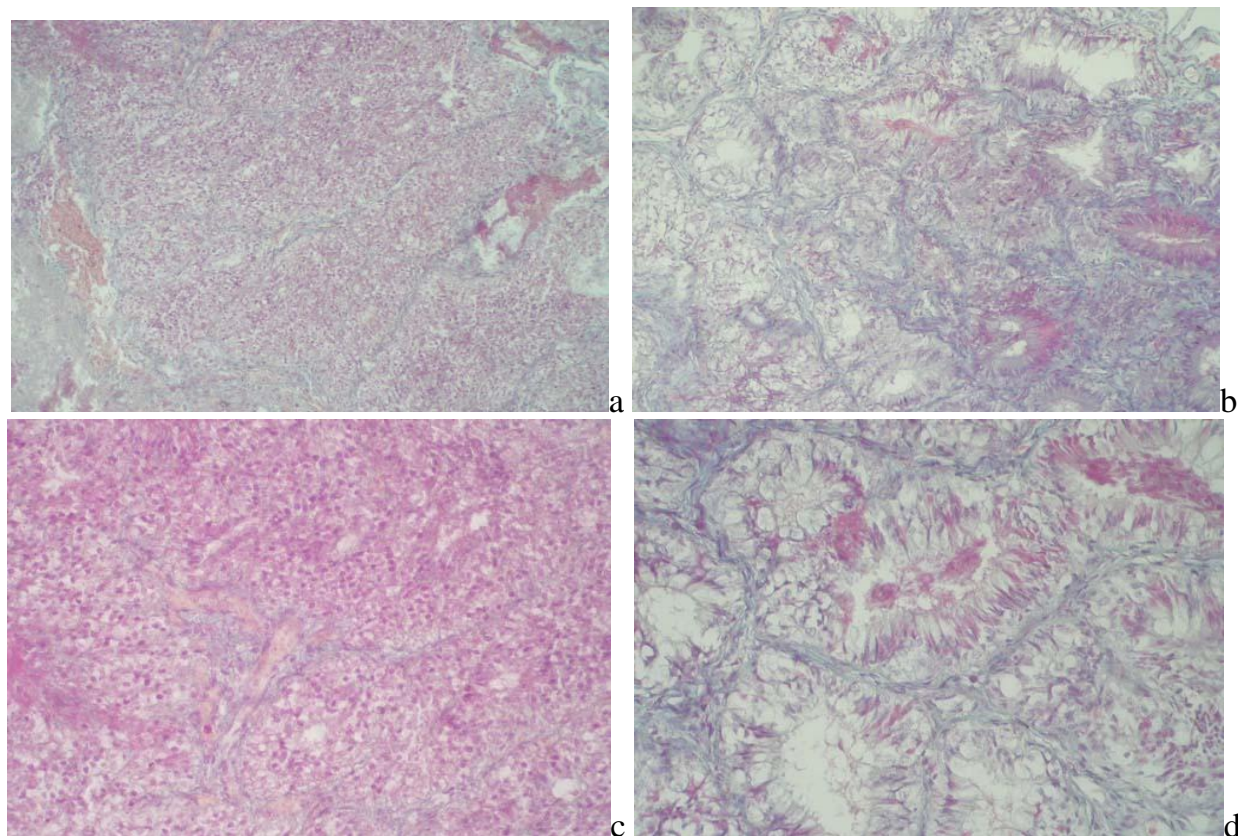

Figure 1. Turkey. Pineal gland at 20 weeks. a) the connective tissue septa has been noted; b) supporting cells and ependymal-like cells are slim with microvilli or cilia; c) the increase in the percentage of parafollicular cells; d) secretory pinealocytes in the distal part of the pineal stalk. HEA x60 (a); x20 (b); PAS stain x100 (c); x400 (d)
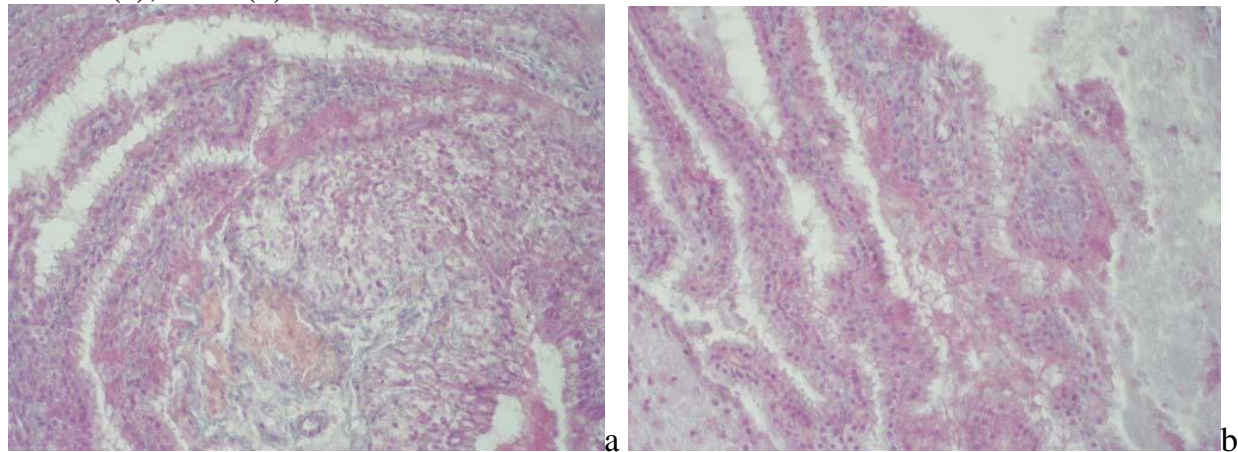

Figure 2.a. Turkey. Pineal gland surrounded by choroids, b. cuboid epithelium of the choroids a. HEA $\times 100$, b. HEA x 200
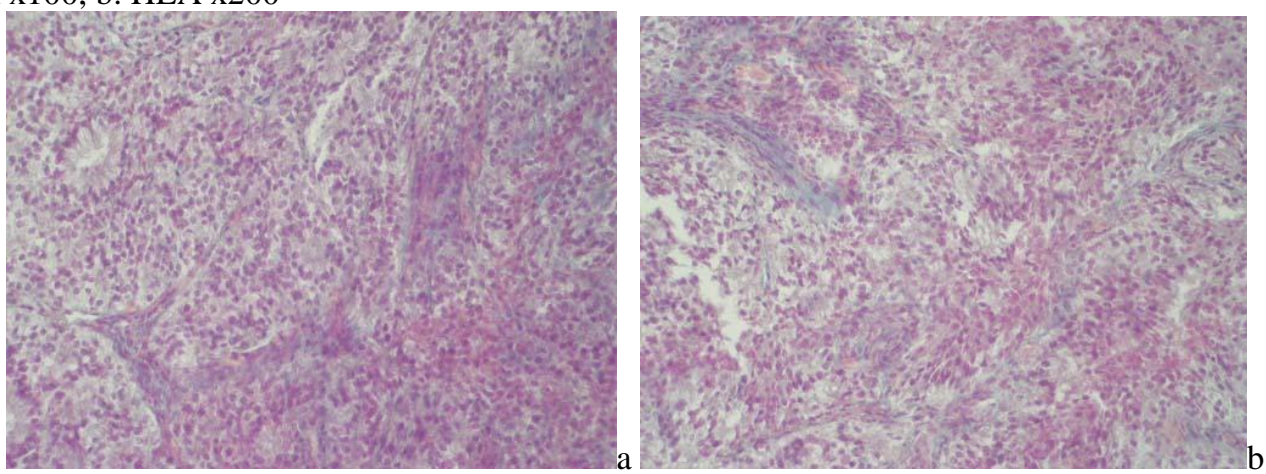

Figure 3. Turkey. Pineal gland subjected to an extended light schedule. a) numerous pinealocytes loaded with positive PAS secretion; b) epiphysis after a normal circadian cycle. The rate of the cells loaded with hormones is lower. PAS x100. 
The present study extends these findings and demonstrates that the duration of elevated melatonin in the turkey pineal gland and retina changes potently in response to the length of the dark phase of the imposed L/D cycle. Increasing experimental evidence indicates that in both mammals and birds, the circadian system plays an important role in photoperiodic time measurement. It has been postulated that the avian circadian timing system might be more complex than in mammals, and involves three autonomous and anatomically distinct multiple central oscillators that are located in the eyes, the hypothalamus, and the pineal gland. The functional significance of these oscillators for circadian regularity varies markedly among avian.

These findings show that in the turkey, photoperiod plays an important role in regulating the melatonin signal.

The vesicles contain a secretory product, which includes a sulphated mucopolysaccharide component. Based on the intensities of the staining reactions, this secretion is present in greatest amounts during the night.

Melatonin is a hormone secreted by the pineal gland, mostly in the dark period of the light/dark cycle, with corresponding fluctuations reflected in the plasma melatonin levels. This hormone plays a critical role in the regulation of various neural and endocrine processes that are synchronized with daily change in photoperiod. Abnormal melatonin levels are associated with metabolic disturbances and other disorders.

\section{CONCLUSIONS}

1. Due to continuous light, the program achieved a large increase in somatic development. 2. Pinealectomy photic led to increased commercial value of the carcasses through increased efficiency of the chest. 3. Density of muscular fibers per area unit was observed with a maximum density at lower member musculature, respectively at the muscular sample gathered at thigh level, in comparison with minimal value recorded for meat samples gathered from the pectoral zone. 4. Turkeys subjected to a normal light schedule present pinealocytes with the poorest cytoplasm in hormones or the rate of the loaded pinealocytes is lower. This hormone plays a critical role in the regulation of various neural and endocrine processes that are synchronized with daily changes in photoperiod.

\section{REFERENCES}

ARENDT, J.; PÉVET, P. Advances in pineal research. London: John Libbey, London, 1991. v. 5, p. 27

ARENDT, J. Melatonin and the mammalian pineal gland. London: Chapman and Hall, 1995.

BOIŞTEANU, P.C. Glanda pineală şi rolul ei în creştere şi dezvoltare la păsări. Iasi: Editura Corson, 2000.

BUIJS, R.M.; SCHEER, F.A.; KREIER, F. et al. Organization of circadian functions: interaction with the body. Prog. Brain Res., v.153, p.341360, 2006.

BRANDSTATTER, R. Encoding time of day and time of year by the avian circadian system. $J$. Neuroendocrinol., v.15, p.398-404, 2003.

CANTWELL, E.L.; CASSONE, V.M. Chicken suprachiasmatic nuclei: II. Autoradiographic and immunohistochemical analysis. J. Comp. Neurol., v.499, p.442-457, 2006.

CHONG, N.W.; CHAURASIA, S.S.; HAQUE, R. et al. Temporal-spinal characterization of chicken clock genes: circadian expression in retina, pineal gland, and peripheral tissues. $J$. Neurochem., v.85, p.851-860, 2003.

CSERNUS, V.; BÉLA MESS: Biorhythms and pineal gland. Neuroendocrinol. Letters, v.24, p.404-411, 2003.

FOSTER, R.G.; HANKINS, M.W. Non-rod, non-come photoreception in the vertebrates. Prog. Retin. Eye Res., v.21, p.507-527, 2002.

GWINNER, E.; BRANDSTUTTER, R. Complex bird clocks. Philos Trans $R$ Soc Lond B. Biol. Sci., v.356, p.1801-1810, 2001.

LEWIS, P.D.; DANISMAN, R.; GOUS, M.R. Photoperiod for broiler breeder females during the laying period. Poult. Sci., v.89, p.108-114, 2010.

LORENC-DUDA, A.; BEREZINSKA, M.; BATHOREL, B. et al. Turkey retina and pineal gland differentially respond to constant environment. J. Comb. Physiol. A, v.194, p.907913, 2008. 
MICHAEL, J.B.; VINCENT, M.C. Melanopsin expression in the chick retina and pineal gland. Mol. Brain Res., v.134, p.345-348, 2005.

NATESAN, A.; GEETHA, L.; ZATZ, M. Rhythm and soul in the avian pineal. Cell Tissue Res., v.309, p.35-45, 2002.

OKANO, T.; FUKADA, Y. Chicktacking pineal clock. J. Biochem., v.134, p.791-797, 2003

PRZYBZLSKA, G.B.; LEWEZUK, B.; PRUSIK, M.; BULC, M. Pineal concentrations in turkey (Meleagris gallopavo) as a result of collagenmediate calcification. Histol. Histopathol., v.24, p.407-415, 2009.

SCHOMERUS, C.; KORF, H.W. Mechanisms regulating melatonin synthesis in the mammalian pineal organ. Ann NY Acad. Sci., v.1057, p.372$383,2005$.

SIAPES, T.D.; EL HALAWANI, M.G. Pineal and ocular influences on male female turkeys: plasma luteinizing hormone and prolactin levels during gonadal development. Gen. Comp. Endocrinol., v.73, p.284-293, 1989.

SKENE, D.J.; VIVIEN-ROELS, B.; PÉVET, P. Day and night time concentrations of 5methoxztryphophol and melatonin in the retina and pineal gland from different classes of vertebrates. Gen. Com. Endocrinol., v.84, p.405$411,1991$.
SKWARLO-SONTA, K. Reciprocal interdependence between pineal gland and avian immune system. NEL Rev. Neuroendocrinol., v.20, p.151-156, 1999.

UNDERWOOD, H.; STEELE, C.T.; ZIVKOVIC, B. Circadian organisation and the role of the pineal in birds. Microsc. Res. Tech., v.53, p.207-215, 2001.

ZAWILSKA, J.B.; BEDNAREK, A.; BEREZISKA, M.; NOWAK, J.Z. Rhythmic changes in metabolism of dopamine in the chick retina: the importance of light versus biological clock. $J$. Neurochem., v.84, p.717-724, 2003.

ZAWILSKA, J.B.; LORENC, A.; BEREZISKA, M. et al. Daily oscillation in melatonin synthesis in the turkey pineal gland and retina: diurnal and circadian rhythms. Chronobiol. Int., v.23, p.341350, 2006a.

ZAWILSKA, J.B.; LORENC, A.; BEREZISKA, M. et al. Diurnal and circadian rhythms in melatonin synthesis in the turkey pineal gland and retina. Gen. Comp. Endocrinol., v.145, p.162-168, 2006b. 